\title{
The origin of biodegraded oils in the sandstone reservoir in the Termit Basin, Niger
}

\author{
WenQIANG WANG ${ }^{1,3}$, TIEguAN WANG ${ }^{1}$, MEIJUN Li ${ }^{1,2, *}$ \\ ${ }^{1}$ State Key Laboratory of Petroleum Resources and \\ Prospecting, College of Geosciences, China University of \\ Petroleum, Beijing 102249, China \\ (*correspondence: meijunli@cup.edu.cn) \\ ${ }^{2}$ Key Laboratory of Exploration Technologies for Oil and \\ Gas Resources, Ministry of Education, College of \\ Resources and Environment, Yangtze University, Wuhan \\ 430100, China \\ ${ }^{3}$ Research Institute of Yanchang Petroleum (GROUP) Co. \\ Ltd, Xi'an 710075, China
}

Biodegradation is a common secondary alteration process for subsurface reservoired oils and substantially effect the physical and chemical properties, making recovery and refining of degraded oils more costly.

The Upper Cretaceous Yogou Formation is the principal source bed and the Eocene Sokor Formation is the major reservoir in the Termit Basin (Niger). A total of 35 oils collected from Yogou to Sokor formations in nine differrnt tectnoic units were geochemically analyzed. This study attempts to investigate the geochemical characteristics and possible origins of crude oils in Termit Basin.

The results of oil-oil correlation show that these crude oils are genetically identical and derived from the same source kitchen. Differences in physical properties and geochemical compositions may be attributed to secondary alteration, such as biodegradation. Lightly, moderately and severely biodegraded oils can be divided on the basis of the relative abundance of $n$-alkanes and acyclic isoprenoids in the oils and the presence of "humps"on gas chromatogram baselines, as well as of the relative abundance of 25norhopanes.

The API gravity of Termit Basin crude oils generally increases with burial depth. All crude oils with a burial depth of less than $1400 \mathrm{~m}$ were apparently subjected to distinct biodegradation reflected in not only API gravity but also biomarker parameters, (e.g., relatively higher $\operatorname{Pr} / n \mathrm{C}_{17}$ and $\mathrm{Ph} / n \mathrm{C}_{18}$ ). Furthermore, oil traps and external reservoirs close to the adjacent unclosed faults and the relatively early oil charging are favorable for biodegradation. This study may have practical application for further petroleum exploration and development in the Termit Basin. 